\title{
PENGARUH VARIASI VARIABEL REAKSI PADA PROSES EKSTRAKSI REAKTIF MESOKARP SAWIT UNTUK MENGHASILKAN BIODIESEL
}

\author{
Pascalis Novalina ${ }^{1}$, Arya Josua $\mathrm{S}^{1}$, Taslim ${ }^{1}$, Tjahjono Herawan ${ }^{2}$ \\ ${ }^{1}$ Departmen Teknik Kimia, Fakultas Teknik Universitas Sumatera Utara, Sumatera Utara \\ Jl. Almamater Kampus USU Medan 20155, Indonesia \\ ${ }^{2}$ Pusat Penelitian Kelapa Sawit, Medan 20158, Indonesia \\ E-mail :pascalisnovalina@ rocketmail.com
}

\begin{abstract}
Abstrak
Metode konvensional untuk produksi biodiesel memerlukan minyak yang diekstrak dari biomassa sebelum dapat ditransesterifikasikan menjadiasam lemak metil ester (FAME). Ekstraksi reaktif dapat digunakan untuk menghasilkan biodiesel denganperolehan yield tinggi, biaya produksi yang rendah, mengurangi waktu reaksi dan penggunaan reagen serta co-pelarut, sehingga mempermudah untuk menghasilkan biodiesel. Dalam penelitian ini, ekstraksi reaktif diterapkan untuk menghasilkan biodiesel dari CPO hasil ekstraksi mesokarp buah sawitmenggunakan dimetil karbonat sebagai pelarut dan reagen, dan novozym ${ }^{\circledR}$ 435 sebagai katalis. Metanol digantikan oleh dialkil karbonat, terutama dimetilkarbonat. Dimetil karbonat dapat digunakan sebagai pelarut dan sebagai reagen, sehingga ekstraksi reaktif sangat mudah untuk diaplikasikan. Parameter yang dipelajari meliputi suhu reaksi $\left(50,60\right.$, dan $\left.70{ }^{\circ} \mathrm{C}\right)$, waktu reaksi $(8,16,24$ jam), rasio molar reaktan DMC/mesokarp sawit $(50: 1,60: 1,70: 1 \mathrm{n} / \mathrm{n})$, jumlah konsentrasi novozym ${ }^{\circledR} 435$ (5\%, 10\%, 15\% wt). Danyield biodiesel tertinggi diperoleh pada kondisi suhu reaksi $60{ }^{\circ} \mathrm{C}$, waktu reaksi 24 jam, rasio molar reaktan DMC/mesokarp sawit 60:1 (n/n), dan konsentrasi novozym ${ }^{\circledR} 435$ sebesar 10\% b/b. Penelitian menunjukkan bahwa sintesis biodiesel melalui ekstraksi reaktif menggunakan mesokarp buah sawit sebagai bahan bakumemerlukan biaya produksi yang rendah.
\end{abstract}

Kata kunci: biodiesel, dimetil karbonat, ekstraksi reaktif, mesokarp sawit, novozym ${ }^{\circledR} 435$

\begin{abstract}
The conventional method for the production of biodiesel needed the oil that is extracted from the biomass before it can be transesterified into fatty acid methyl esters (FAME). Reactive extraction can be used to produce biodiesel with high-yield, low production costs, reduce the reaction time and the use of reagents and co-solvents, making it easier to produce biodiesel. In this study, reactive extraction applied to produce biodiesel from palm fruit mesocarp extracted using dimethyl carbonate as a solvent and reagents, and novozym ${ }^{1} 35$ as a catalyst. Methanol was replaced by dialkyl carbonates, particularly dimethyl carbonate. Dimethyl carbonate can be used as a solvent and as a reagent, so reactive extraction is very easy to apply. The parameters will be study are reaction temperature $\left(50,60\right.$, and $\left.70{ }^{\circ} \mathrm{C}\right)$, reaction time $(8,16,24$ hours), the molar ratio of reactants $(50: 1,60: 1,70: 1 \mathrm{n} / \mathrm{n})$, the concentration of novozym ${ }^{\circledR} 435(5 \%, 10 \%, 15 \%$ $w t)$.The results showed that the highest biodiesel yield can be achivied at conditions temperature of $60{ }^{\circ} \mathrm{C}$, reaction time 24 hours, molar ratio of reactants palm mesocarp to DMC 1:60, and novozym ${ }^{\circledR} 435$ concentration of $10 \mathrm{wt} \%$. The results showed that the synthesis of biodiesel via reactive extraction using palm mesocarp as raw material requires a low production cost.
\end{abstract}

Keywords:biodiesel, dimethyl carbonate, reactive extraction, oil palm mesocarp, Novozym ${ }^{\circledR} 435$

\section{Pendahuluan}

Saat ini, bahan bakar fosil adalah sumber utama energi global. Namun, diperkirakan bahwa era bahan bakar murah dan mudah diakses akan segera berakhir [16]. Masalah lingkungan muncul seperti peningkatan pemanasan global yang disebabkan oleh pembakaran bahan bakar fosil [11]. Oleh karena itu, untuk mengatasi masalah ini harus ada diversifikasi energi dengan mencari energi terbarukan alternatif.

Salah satu energi alternatif yang berasal dari sumber daya terbarukan dari makanan dan nonmakanan adalah biodiesel [32]. Biodiesel merupakan bahan bakar terbarukan, biodegradable, tidak beracun, dan ramah lingkungan. Biodiesel menghasilkan emisi yang lebih rendah, memiliki titik nyala yang tinggi, pelumas daya yang lebih baik, dan cetane number tinggi. Penggunaan biodiesel memiliki potensi untuk mengurangi tingkat polusi dan mungkin karsinogen [18].

Bahan baku yang digunakan untuk produksi biodiesel bervariasi tergantung pada wilayah geografis dan kondisi budidaya dan ketersediaan [9]. Indonesia merupakan salah satu produsen minyak sawit terbesar di dunia. Total luas perkebunan di Indonesia adalah sekitar 8 juta hektar dan diperkirakan mencapai 13 juta hektar pada tahun 2020. Indonesia menghasilkan lebih dari 23 juta ton minyak sawit pada tahun 2012 [3]. Daya tarik buah kelapa terletak pada kandungan minyak yang tinggi, jauh melebihi dari minyak nabati lainnya, dan biaya produksi yang lebih rendah [22]. 
Oleh karena itu, penggunaan buah sawit sebagai bahan baku biodiesel selain murah, berlimpah ketersediaannya langkah penting menuju proses produksi biodiesel dan berkelanjutan

Dalam proses produksi biodiesel, proses kimia transesterifikasi banyak digunakan. Namun ia memiliki beberapa kelemahan seperti pemulihan katalis dan pemurnian gliserol sulit dan membutuhkan banyak air cuci. Penggunaan katalis enzim dapat mengatasi kelemahan tersebut. Proses enzimatik mampu bereaksi pada kondisi suhu moderat, pemulihan produk lebih mudah, dan konversi produk yang tinggi [2].

Enzim lipase adalah salah satu yang cocok sebagai katalis untuk transesterifikasi dari berbagai bahan baku, bahan baku bahkan dengan nilai asam tinggi, yang dianggap sebagai bahan baku berkualitas rendah. Jenis immobilized lipase (IL) yang paling umum adalah Novozym ${ }^{\circledR} 435$, Candida antarctica lipase B [9,10,34]. Metode konvensional untuk produksi biodiesel membutuhkan minyak yang diekstrak dari biomassa sebelum dapat ditransesterifikasikan menjadi ester. Ini adalah proses yang panjang [3]. Ekstraksi dan transesterifikasi dapat terjadi dalam satu langkah, dimana alkohol bertindak sebagai pelarut ekstraksi dan reagen transesterifikasi [26].

Namun, dalam transesterifikasi enzim-katalis, metanol menunjukkan efek negatif pada aktivitas enzim sehingga menurunkan hasil produksi [1]. Oleh karena itu, untuk meningkatkan aktivitas enzim dan konversi biodiesel digunakan dimethylcarbonate (DMC) sebagai substitusi dari metanol. DMC dapat digunakan sebagai pelarut dan sebagai reagen. DMC marupakan pelarut yang ramah lingkungan, tidak berbau, non-korosif, dan tidak beracun [8].

Oleh karena itu, tujuan dari penelitian ini adalah untuk mempelajari teknologi pembuatan biodiesel dari mesokarp buah sawit dengan metode teknologi ekstraksi reaktif., mengamati pengaruh variabel waktu reaksi, rasio mol mesokarp terhadap DMC, dan jumlah katalis Novozym 435 dalam proses sintesis biodiesel dan menganalisis sifat fisik biodiesel yang dihasilkan.

\section{Teori}

\section{Ekstraksi Reaktif}

Ekstraksi reaktif merupakan proses langsung di mana semua padat, pelarut dan katalis dicampur dalam satu fase untuk mendapatkan ester metil lebih tinggi. Dengan kata lain, dalam proses ini, alkohol bertindak baik sebagai ekstraksi pelarut dan pereaksi transesterifikasi selama proses ekstraksi reaktif [12]. Ekstraksi reaktif dapat digunakan untuk mencapai yield biodisel tinggi dan membantu untuk mengurangi biaya produksi serta menyederhanakan proses itu sendiri. Hal ini juga dapat mengurangi waktu reaksi dan penggunaan reagen dan co-pelarut [27]. Berdasarkan katalis yang digunakan dalam proses ekstraksi reaktif, metode produksi biodiesel dapat secara luas diklasifikasikan ke dalam dua kategori: berbasis transesterifikasi kimia dan enzimatik [13]. Ekstraksi reaktif menggunakan katalis padat memiliki biaya operasi yang lebih rendah dan lebih kompatibel lingkungan [31]. Produksi biodiesel dengan teknologi ekstraksi reaktif dipengaruhi oleh enam parameter yaitu: ukuran partikel, kecepatan pengadukan, suhu reaksi, waktu reaksi, konsentrasi katalis dan rasio molar alkohol minyak [14].

Dalam penelitian ini, ekstraksi reaktif dilakukan dalam erlenmeyer dilengkapi dengan pengaduk dan pemanas. Mesokarp kelapa sawit dimasukkan ke dalam erlenmeyer berukuran $50 \mathrm{ml}$, dan Novozym $^{\circledR} 435$ digunakan sebagai katalis transesterifikasi. Variabel yang diteliti adalah reaksi konsentrasi enzim $(5 \%, 10 \%, 15 \% \mathrm{wt})$, waktu reaksi $(8,16,24$ jam $)$, suhu reaksi $\left(50-70{ }^{\circ} \mathrm{C}\right)$, dan rasio mol reaktan (50: 1, 60: 1, 70: 1). Campuran dipanaskan sampai suhu reaksi yang diinginkan dengan kecepatan pengadukan $300 \mathrm{rpm}$. Setelah tercapai waktu reaksi, campuran didinginkan dan kemudian disaring melalui kertas saring. Residu padat dicuci berulang kali dengan DMC, dan kelebihan DMC dalam filtrat di dipulihkan menggunakan rotary evaporator. Setelah penguapan, campuran metil ester ditimbang dan dicatat.

\section{Dimetil Karbonat (DMC)}

Dimetil karbonat (DMC) dihasilkan dari metanol, karbon monoksida dan oksigen. DMC merupakan senyawa serbaguna yang memiliki reaktivitas kimia, sifat fisik yang lebih baik dibandingkan dengan metanol dan metil asetat [20]. Dimetil karbonat dapat digunakan sebagai pelarut, resin fungsional, dan intermediet kimia polar untuk berbagai jenis senyawa organik [20]. Su et al. [24] telah melaporkan produksi biodiesel menggunakan dimetil karbonat (DMC) sebagai akseptor asil dapat menghilangkan resiko penonaktifan lipase yang disebabkan oleh alkohol rantai pendek. Selain itu, reaksi antara minyak dan DMC tidak bisa kembali, dan karenanya meningkatkan kecepatan reaksi dan meningkatkan hasil biodiesel [24,25]. Dimetil karbonat (DMC) merupakan sebuah alternatif pengganti metanol sebagai akseptor asil dan bahan kimia ramah lingkungan karena sifat netral, tidak berbau, non-korosif dan tidak beracun [8]. Selain itu, tidak ada gliserol yang dihasilkan selama proses transesterifikasi minyak dan DMC dalam pembuatan biodiesel [33].

\section{Novozym $^{\circledR} 435$}

Novozym $^{\circledR} 435$ dapat digunakan untuk mengkatalisis transesterifikasi dan hidrolisis reaksi untuk produksi biodiesel. Novozym ${ }^{\circledR} 435$ memiliki struktur berpori dan lebih sensitif terhadap perubahan dalam rasio mol dan dapat mencapai konversi yang tinggi dengan rasio mol, suhu dan jumlah katalis lebih rendah [10]. 


\begin{abstract}
Metodologi Penelitian
Bahan Baku dan Pereaksi

Mesokarp sawit yang digunakan dalam penelitian ini disediakan oleh Pusat Penelitian Kelapa Sawit, Medan, Indonesia. Dimetil karbonat (kemurnian> 99,0\%) dibeli dari Merck, Jerman. Senyawa Novozym ${ }^{\circledR} 435$ dibeli dari standar Bagsværd, Denmark.
\end{abstract}

\section{Persiapan Mesokarp Sawit}

Sebagai langkah pertama, mesokarp dipisahkan dari inti sawit (kernel). Untuk penentuan kadar asam lemak total, sebanyak 5 gram sampel mesokarp segar dikeringkan di dalam oven pada suhu $105{ }^{\circ} \mathrm{C}$. Mesokarp kering ditempatkan di erlmeneyer tertutup untuk ekstraksi soxhlet selama 24 jam menggunakan heksana sebagai pelarut ekstraksi. Heksana di uapkan menggunakan rotary evaporator dan minyak hasil ekstraksi ditimbang. Kandungan minyak total yang kuantitatif ditentukan secara gravimetri. Kandungan minyak dihitung dari rasio jumlah minyak yang diekstraksi oleh sampel berat. Nilai ini digunakan sebagai berat total minyak dalam sampel dalam perhitungan produk reaksi.

\section{Prosedur Ekstraktif Reaksi}

Ekstraksi reaktif dilakukan dalam erlenmeyer berukuran $50 \mathrm{ml}$ sebagai reaktor. Sebanyak 2 gram mesokarp sawit dimasukkan ke dalam erlenmeyer, Novozym $^{\circledR} 435$ dibungkus menggunakan kertas saring membentuk segi empat dan dimasukkan kedalam reaktor sebagai katalis reaksi. DMC dimasukkan kedalam campuran tersebut, reaktor ditutup kemudian dipanaskan sampai suhu reaksi yang diinginkan dan diaduk menggunakan magnetic stirrer dengan kecepatan pengadukan $300 \mathrm{rpm}$. Setelah reaksi berjalan selama 24 jam, campuran didinginkan dan kemudian disaring melalui kertas saring. Residu padat dicuci berulang kali dengan DMC, dan kelebihan DMC dalam filtrat di pulihkan menggunkaan vacuum rotary evaporator. Setelah penguapan, campuran metil ester ditimbang beratnya lalu dicatat.

\section{Analisis Kimia}

Kompoisisi Bahan Baku dan Kemurnian Biodiesel

Komposisi bahan baku mesokarp buah sawit dan kemurnian biodiesel akan dianalisis menggunakan instrumen Gas Chromatography - Mass Spectrometry (GCMS) di Pusat Penelitian Kelapa Sawit Medan, Sumatera Utara.

\section{Analisis Viskositas dan Densitas Biodiesel \\ Untuk Analisis viskositas dan densitas menggunakan instrumen Stabinger Viscosimeter spesifikasi SVM 3000 di Pusat Penelitian Kelapa Sawit Medan, Sumatera Utara.}

\author{
Hasil dan Pembahasan \\ Hasil Analisis Bahan Baku Mesokarp Buah Sawit \\ Kandungan minyak yang diperoleh dalam \\ mesokarp buah sawit adalah 83,324\%.
}

Tabel 1. Komposisi Asam Lemak dari CPO (Crude Palm Oil)

\begin{tabular}{|l|c|}
\hline \multicolumn{1}{|c|}{ KomponenPenyusun } & $\begin{array}{c}\text { Komposisi \% } \\
(\mathbf{b} / \mathbf{b})\end{array}$ \\
\hline Asam Miristat $\left(\mathrm{C}_{14: 0}\right)$ & 1,0843 \\
\hline Asam Palmitat $\left(\mathrm{C}_{16: 0}\right)$ & 47,5118 \\
\hline Asam Palmitoleat $\left(\mathrm{C}_{16: 1}\right)$ & 0,1965 \\
\hline Asam Stearat $\left(\mathrm{C}_{18: 0}\right)$ & 3,5314 \\
\hline Asam Oleat $\left(\mathrm{C}_{18: 1}\right)$ & 38,3876 \\
\hline Asam Linoleat $\left(\mathrm{C}_{18: 2}\right)$ & 8,4687 \\
\hline Asam Linolenat $\left(\mathrm{C}_{18: 3}\right)$ & 0,3086 \\
\hline Asam Arakidat $\left(\mathrm{C}_{20: 0}\right)$ & 0,3649 \\
\hline Asam Eikosenoat $\left(\mathrm{C}_{20: 1}\right)$ & 0,1461 \\
\hline
\end{tabular}

Berdasarkan data komposisi asam lemak dari CPO maka dapat ditentukan bahwa berat molekul CPO (dalam bentuk trigliserida) adalah 857,1361 gr/mol sedangkan berat molekul FFA CPO adalah 273,0454 gr/mol.

Minyak dan lemak nabati, asam lemak jenuh umumnya terdapat pada posisi luar sn-1 dan sn-3 sedangkan asam lemak tak jenuh pada bagian dalam sn-2 [21]. Umumnya, lipase dibagi menjadi tiga tipe diantaranya ialah lipase 1,3-spesifik (menghidrolisis ikatan ester pada posisi $R_{1}$ atau $R_{3}$ trigliserida), lipase 2-spesifik (menghidrolisis ikatan ester pada posisi $R_{2}$ trigliserida) dan lipase non-spesifik (tidak membedakan antara posisi ikatan ester) [29]. Komposisi asam lemak jenuh sebesar 52,4925\% dan Asam Lemak tak Jenuh 47,5075 \%/. Berdasarkan komposisi asam lemak jenuh dan tidak jenuh dalam CPO dimana asam lemak yang lebih dominan adalah asam lemak jenuh yaitu sekitar 52,4925\% dengan posisi sn-2 maka penggunaan enzim yang non spesifik seperti Novozym ${ }^{\circledR} 435$ memungkinkan akan memberikan hasil yang baik.

\section{Pengaruh Rasio Molar Reaktan terhadap Perolehan Yield Metil Ester}

Hubungan rasio molar reaktan terhadap yield metil ester diperlihatkan pada gambar 1 .

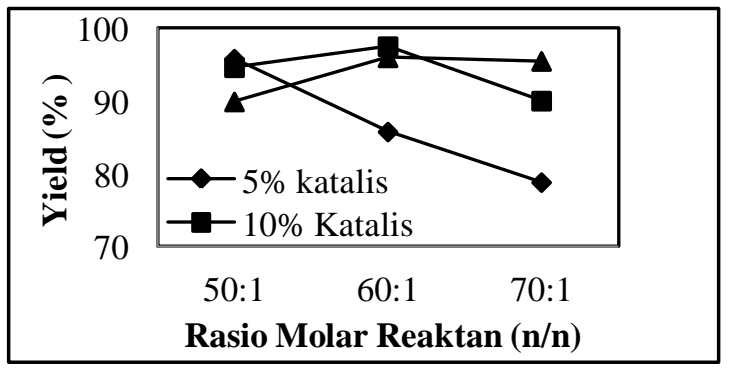

Gambar 1. Hubungan antara Rasio Molar Reaktan terhadap Perolehan Yield Metil Ester, Pada Waktu Reaksi 24 Jam, Suhu Reaksi $60{ }^{\circ} \mathrm{C}$, Kecepatan Pengadukan 300 rpm. 
Dari gambar 1 dapat dilihat hubungan antara rasio molar reaktan terhadap perolehan yield metil ester dengan berbagai variasi konsentrasi katalis novozym $^{\circledR} 435$, grafik tersebut menunjukkan bahwa pada konsentrasi katalis 5\% semakin besar rasio molar reaktan yang digunakan maka yield yang dihasilkan akan semakin kecil atau mengalami penurunan, sedangkan pada konsentrasi katalis $10 \%$ dan $15 \%$ persen, diperoleh kondisi perbandingan reaktan terbaik pada rasio reaktan 60:1. Gambar 2 menunjukan reaksi trigliserida dengan dimetilkarbonat.

$$
\text { Trigliserida Dimetil karbonat }
$$

Gambar 2. Reaksi Transesterifikasi Enzimatis dari Trigliserida Menjadi Metil Ester Menggunakan Pelarut Dimetil Karbonat (Seong et al., 2011)

Berdasarkan stokiometri reaksi transesterifikasi minyak mesokarp sawit dengan menggunakan pelarut DMC dibutuhkan 1,5 mol DMC untuk setiap pembentukan 3 mol biodiesel. Proses reaktif ekstraksi meliputi proses ekstraksi minyak dari mesokarp sawit dan proses transesterifikasi ester yang terjadi dalam satu tahap tunggal dimana alkohol berfungsi sebagai pelarut dan reagen pereaksi sekaligus. Sehingga dalam proses ini dibutuhkan jumlah pelarut yang lebih banyak [12].

Pada gambar 1 terlihat peningkatan lebih lanjut hingga rasio reaktan 70:1. Semakin bertambahnya jumlah dimetil karbonat yang digunakan pada penelitian, perolehan yield metil ester semakin kecil atau semakin menurun. Rasio reaktan yang terlalu tinggi menyebabkan kelebihan DMC yang dapat mengakibatkan konsentrasi minyak dalam sistem menjadi lebih encer, sehingga frekuensi tumbukan antar partikel minyak dan lipase berkurang $[6,15]$.

Selain itu, perolehan metil ester yang semakin menurun ini disebabkan oleh menurunnya kinerja novozym $^{\circledR} \quad 435$ dalam proses reaktif ekstraksi. Penggunaan dimetil karbonat sebagai reaktan dalam proses produksi biodiesel secara enzimatis dapat menghilangkan resiko deaktivasi lipase yang disebabkan oleh alkohol rantai pendek. Su et al. [24] membuktikan bahwa DMC memberikan konversi dua sampai tiga kali lebih tinggi dibandingkan asil akseptor konvensional seperti metanol dan metil asetat.Kinerja novozym ${ }^{\circledR} 435$ yang semakin menurun kemungkinan disebabkan oleh inhibitor pada sisi aktif pori-pori novozym ${ }^{\circledR} 435$ yaitu terakumulasinya minyak sawit yang belum sepenuhnya terkonversi menjadi metil ester. Minyak sawit yang terakumulasi pada novozym ${ }^{\circledR} 435$ berupa asam oleat [4]. Asam oleat yang terkandung dalam CPO yang dipakai sebagai bahan baku cukup tinggi yaitu sebesar $38,3876 \%$.
Pengaruh Konsentrasi Katalis Novozym $^{\circledR} 435$ terhadap Perolehan Yield Metil Ester

Pengaruh konsentrasi katalis novozym ${ }^{\circledR} 435$ terhadap yield metil ester yang diperoleh pada penelitian ini diperlihatkan pada gambar 3 .

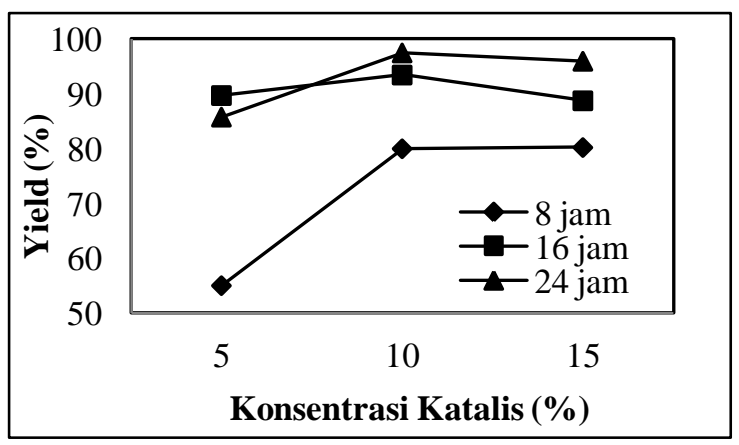

Gambar 3. Pengaruh Konsentrasi Katalis Novozym $^{\circledR} 435$ terhadap Perolehan Yield Metil Ester, Pada Rasio Reaktan 60:1, Suhu Reaksi 60 ${ }^{\circ} \mathrm{C}$, Kecepatan Pengadukan 300 rpm

Hubungan antara konsentrasi katalis novozym ${ }^{\circledR}$ 435 terhadap yield metil ester dengan berbagai variasi waktu reaksi pada rasio molar reaktan tetap 60:1 dan suhu reaksi tetap $60{ }^{\circ} \mathrm{C}$ dapat dilihat pada gambar4. Dari gambar 3dapat dilihat bahwa pada waktu reaksi 8 jam, 16 jam, dan 24 jam terjadi peningkatan yield metil ester dari konsentrasi katalis $5 \%$ - 10\%, namun pada penggunaan katalis $15 \%$ mengalami penurunan. Pada penggunaan katalis 5\% - $15 \%$ mengalami peningkatan yield metil ester mulai waktu reaksi 8 jam - 24 jam, hingga didapatkan perolehan yield metil ester tertinggi pada penggunaan katalis $10 \%$ dengan waktu reaksi 24 jam. Penggunaan katalis membantu untuk mempercepat proses transesterifikasi minyak menjadi metil ester dan secara tidak langsung juga meningkatkan jumlah produk yang dihasilkan dari proses reaktif ekstraksi dibandingkan proses ekstraksi tunggal. Perbedaan efisiensi ekstraksi dan fasa dikarenakan produk metil ester bertindak sebagai $c o$ solvent [12].

Perolehan yield metil ester mengalami penurunan pada konsentrasi katalis $15 \%$. Hal ini mengindikasikan bahwa konsentrasi katalis $10 \%$ sudah cukup untuk mengubah minyak sawit menjadi metil ester melalui proses transesterifikasi. Jumlah katalis yang terlalu banyak menyebabkan campuran reaktan menjadi terlalu kental, sehingga memperlambat kecepatan pengadukan [33], dan konsentrasi substrat yang tinggi dapat menyebabkan substrat inhibitor. Jumlah novozym ${ }^{\circledR}$ 435yang lebih banyak, terkait pada active site yang lebih banyak pula. Active site dari novozym ${ }^{\circledR} 435$ berperan penting dalam pembentukan biodiesel khususnya pada pertukaran ikatan asam lemak [30]. 


\section{Pengaruh Waktu Reaksi terhadap Perolehan Yield Metil Ester}

Pengaruh waktu reaksi terhadap perolehan yield metil ester yang diperoleh pada penelitian ini diperlihatkan pada gambar 4.

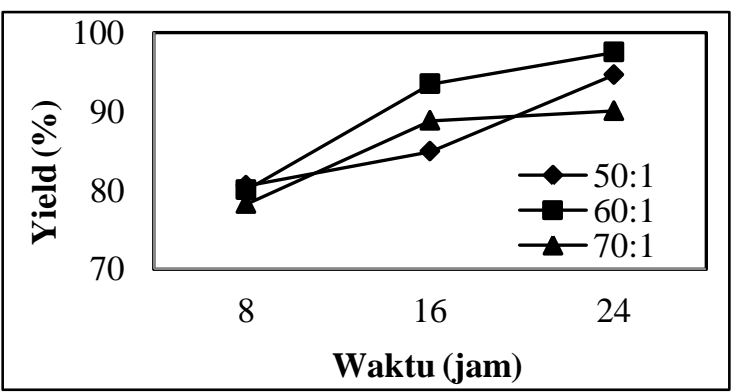

Gambar 4. Pengaruh Waktu Reaksi terhadap Perolehan Yield Metil Ester, Pada Konsentrasi Katalis Novozym ${ }^{\circledR} 43510 \%$, Suhu Reaksi $60^{\circ} \mathrm{C}$, Kecepatan Pengadukan 300 rpm

Dari gambar 4 dapat dilihat bahwa pada rasio molar reaktan 60:1 dan 70:1 mengalami peningkatan yield metil ester mulai waktu reaksi 8 jam - 24 jam, sedangkan pada rasio reaktan 50:1 mengalami penurunan pada waktu reaksi 16 jam.

Pada penelitian ini, saat waktu 8 jam pertama diperoleh yield metil ester pada rasio 50:1 sebesar $80,58 \%$, pada rasio $60: 1$ sebesar $80,25 \%$, dan pada rasio 70:1 sebesar $78,26 \%$. Namun, setelah 8 jam reaksi peningkatan yield tidak terlalu signifikan. Pada waktu reaksi 24 jam diperoleh yield metil ester untuk rasio 50:1 sebesar 94,61\%, untuk rasio 60:1 sebesar $97,49 \%$, untuk rasio 70:1 sebesar 90,03\%. Hal ini disebabkan karena adanya akumulasi produk saat reaksi berlangsung sehingga mengurangi luas permukaan reaksi enzimatisnya [6].

Peningkatan yield metil ester dapat disebabkan oleh bertambahnya waktu reaksi. Pertama-tama, reaksi berjalan lambat sesuai dengan kecepatan pengadukan dan pendispersian alkohol serta minyak. Setelah itu, reaksi tersebut akan berjalan sangat cepat sampai mencapai konversi ester maksimum [5]. Setelah mencapai waktu reaksi optimum. Penambahan waktu reaksi tidak mempengaruhi penambahan yield metil ester. Selain itu, waktu reaksi juga menjadi faktor penting untuk mengurangi biaya produksi. Pada dasarnya, reaksi transesterifikasi enzimatis dilakukan dengan waktu reaksi diantara 7 jam - 48 jam [7].

Pada waktu reaksi 24 jam sudah banyak terbentuk lapisan metil ester dan sedikit lapisan gliserol. Ini berarti bahwa pada waktu reaksi 24 jam sudah dapat membentuk metil ester. Kondisi terbaik yang didapatkan adalah pada waktu reaksi 24 jam, perbandingan rasio molar reaktan 60:1, konsentrasi katalis novozym ${ }^{\circledR} 43510 \%$, suhu reaksi $60{ }^{\circ} \mathrm{C}$, dan kecepatan pengadukan $300 \mathrm{rpm}$ yang memberikan yieldmetil ester sebesar 97,49\%.

\section{Sifat Fisik Dari Biodiesel \\ Analisis Densitas Biodiesel}

Semakin tinggi rasio molar reaktan maka akan semakin rendah densitas biodisel yang dihasilkan. Setyopratomo,dkk. [20] memaparkan bahwa hal ini dapat disebabkan oleh meningkatnya tingkat konversi akibat meningkatnya laju reaksi dan bergesernya kesetimbangan reaksi. Semakin meningkatnya tingkat konversi trigliserida menjadi metil ester, maka densitas biodisel akan semakin menurun karena densitas metil ester lebih rendah daripada densitas trigliserida. Densitas metil ester ini merupakan besaran intensif yang berkaitan dengan nilai kalor dan daya yang di hasilkan oleh mesin diesel persatuan volume bahan bakar. Menurut Standar Nasional Indonesia biodiesel [23], densitas metil ester pada suhu $40{ }^{\circ} \mathrm{C}$ adalah $850-890 \mathrm{~kg} / \mathrm{m}^{3}$. Dari hasil penelitian, densitas metil ester yang diperoleh sebesar $880,60 \mathrm{~kg} / \mathrm{m}^{3}$.

Dengan demikian, metil ester yang dihasilkan memenuhi standar biodiesel. Jika metil ester mempunyai massa jenis melebihi ketentuan maka akan terjadi reaksi yang tidak sempurna pada konversi minyak nabati. Biodiesel dengan mutu seperti ini tidak dapat di gunakan untuk mesin diesel karena akan meningkatkan keausan mesin, emisi dan menyebabkan kerusakan pada mesin [17].

\section{Analisis Viskositas Biodiesel}

Viskositas adalah sifat fisik yang paling penting dari biodiesel karena dapat mempengaruhi pengoperasian injeksi pada peralatan bahan bakar, khususnya pada suhu rendah ketika peningkatan viskositas mempengaruhi fluiditas bahan bakar. Viskositas terbagi menjadi dua yaitu viskositas dinamik dan viskositas kinematik. Viskositas dinamik diperoleh secara langsung dengan analisis menggunakan alat viskosimeter dan untuk viskositas kinematik merupakan perbandingan antara viskositas dinamik terhadap densitasnya. Berdasarkan penelitian yang telah dilakukan, viskositas yang dihasilkan sebesar 4,7279 (kg/m.s) pada suhu $40{ }^{\circ} \mathrm{C}$. Viskositas biodiesel yang diperoleh selanjutnya dibandingkan terhadap densitasnya untuk mendapatkan nilai viskositas kinematik. Adapun viskositas kinematiknya sebesar 5,3686 cSt, dimana Viskositas Kinematik Standar Biodiesel (SNI) sebesar 2,3-6,0 cSt.

Viskositas yang tinggi menyebabkan sulitnya atomisasi pada penyemprotan bahan bakar dan operasi kurang akurat akibat injeksi bahan bakar. Hal ini menyebabkan terjadinya proses pembakaran yang tidak sempurna, akan tetapi jika viskositas bahan terlalu rendah dapat menyebabkan kebocoran pada pompa injeksi bahan bakar [28] sehingga harus menggunakan pelumas dengan viskositas cukup tinggi untuk melumasi bagian-bagian yang bergerak pada sistem bahan bakar dan membantu perapat (seal) bagian-bagian yang bergerak untuk mencegah kebocoran [17]. 


\section{Kesimpulan}

Berdasarkan hasil analisis GC, Kandungan minyak yang diperoleh dalam mesokarp buah sawit adalah 83,324\%. Komponen asam lemak yang dominan pada sampel CPO hasil ekstraski mesokarp sawit adalah asam palmitat sebesar $47,5118 \%$ (b/b) dan asam oleat sebesar 38,3876\% (b/b). Kandungan asam lemak jenuh CPO hasil ekstraksi mesokarp sawit sebesar 47,5075\% dan asam lemak tak jenuh sebesar $52,4925 \%$. Kondisi terbaik yang didapatkan adalah pada waktu reaksi 24 jam, perbandingan rasio molar reaktan 60:1, konsentrasi katalis novozym ${ }^{\circledR} 43510 \%$, suhu reaksi $60{ }^{\circ} \mathrm{C}$, dan kecepatan pengadukan 300 rpm yang memberikan yield metil ester sebesar 97,49\%. Dari hasil diperoleh densitas sebesar $867,055 \mathrm{~kg} / \mathrm{m}^{3}$, viskositas kinematik sebesar 3,882 cSt.

\section{Daftar Pustaka}

[1] Baadhe, Rama Raju., RavichandraPotumarthi, Vijai K. Gupta, "Lipase-Catalyzed Biodiesel Production: Techinal Challenges", Bioenergy Research: Advances and Applications, http://dx.doi.org/10.1016/B978-0444-595614.00008-5, 2014.

[2] Diego, Teresa De, Arturo Manjon, Pedro Lozano, da Jose L. Iborra, "A Recylable Enzymatic Biodiesel Production Process In Ionic Liquids", Biosource Technology 102, Hal : 6336 - 6339, 2011.

[3] Febriansyah, Herawan, Ahmad Agus Setiawan, Kutut Suryopratomo, dan Agus Setiawan, "Gama Stove: Biomass Stove For Palm Kernel Shells In Indonesia”, Energy Procedia 47, Hal : 123 - 132, 2014.

[4] Forresti, M.L. \& Ferreira, M.L., "Computational Approach to Solvent-Free of Ethyl Oleate Using Candida Rugosa and Candida Antartica B Lipases, Interfacial Activation and Substrate (Ethanol, Oleic Acid) Adsorption. Biomacromolecules. Vol. 5, No. 6, Hal: 2366-2375, 2004.

[5] Gashaw, Alemaychu dan Teshita, Abile, "Production of Biodiesel from Waste Cooking Oil and Factors Affectng Its Formation: A Review", International Journal of Renewable and Sustainable Energy, 3 (5), Hal: 92 - 98, doi: 10.11648/j.ijrse.20140305.12, 2014.

[6] Gharat, Nikhil dan Rahod, Virendra K., "Ultrasound Assisted Enzyme Catalyzed Transesterification of Waste Cooking Oil with Dimethyl Carbonate", Ultrasonics Sanochemistry, 2012.

[7] Gnanaprakasam, A., V.M Sivakumar, A. Surendhar, M. Thirumarimurugan, dan T Kannadasan, "Recent Strategy of Biodiesel Production from Waste Cooking Oil and Process Influencing Parameters: A Review", Hindawi Publishing Corporation Journal of Energy, Article ID 926392, http://dx.doi.org/10.1155/2013/926392, 2013.
[8] Go, A-Ra, Youngrak Lee, Young Hwan Kim, Sehkyu Park, Joongso Choi, Jinwon Lee, Sung Ok Han, Seung Wook Kim, Chulhwan Park., "Enzymatic Coproduction of Biodiesel and Glycerol Carbonate from Soybean Oil in Solvent-Free System", Enzyme and Microbial Technology, Volume 53, doi:10.1016/j.enzmictec.2013.02.016, pp. 154158. 2013.

[9] Guldhe, Abhishek, Bhaskar Singh, Taurai Mutanda, Kugen Permaul, Faizal Bux, "Advances In Synthesis of Biodiesel Via Enzyme Catalysis: Novel and Sustainable Approaches", Renewable and Sustainable Energy Reviews, 41, Hal : 1447 - 1464, 2015.

[10] Haigh, K. F., S. Z. Abidin, G. T. Vladisavljevic, B. Saha. "Comparison of Novozyme 435 and Purolite D5081 as Heterogeneous Catalyst for the Pretreatment of Used Cooking Oil for Biodiesel Production". Fuel, Volume 111, doi:10.1016/j.fuel.2013.04.056, pp. 186-193. 2013.

[11] Hosseini, Seyed Ehsan dan Mazlan Abdul Wahid, "Utilization of Palm Soild Residu As A Source Renewable And Sustainable Energy In Malaysia", Renewable and Sustainable Energy Reviews, 40, Hal : 621 - 632, 2014.

[12] Jairurob, Ponsak, Chantaraporn Phalakornkule, Anamai Na-udom, Anurak Petiraksakul, "Reactive Extraction of After-Stripping Sterilized Palm Fruit to Biodiesel", Fuel 107, Hal: 282 - 289, 2013.

[13] Jiang, Yanjun, Dan Li, Yang Li, Jing Gao, Liya Zhou, Ying He., "In Situ Self-Catalyzed Reactive Extraction of Germinated Oilseed with Short-Chained Dialkyl Carbonates for Biodiesel Production", Biosource Technology, Vol. 150, pp. 50-54, 2013.

[14] Kasim, Farizul dan Adam P. Harvey, "Influence of Varoius Parameters On Reactive Extraction OfJatropha curcas L. For Biodiesel Production", Chemical Engineering Journal, 171, Hal : 1373 - 1378, 2011.

[15] Koh, M.Y., Ghazi, T.I.M., "A Riview of Biodiesel Production from Jatropha curcas L.Oil," Renewable Sustainable Energy Rev. 15, Hal: 2240 - 2251, 2011.

[16] Luna, Carlos, Cristobal Verdugo, Enrique D Sancho, Diego Luna, Juan Calero, Alejandro Posadillo, Felipa M Baustita, Antonio A Romero., "Production of A Biodiesel-Like Biofuel Without Glycerol Generation, by Using Novozym ${ }^{\circledR}$ 435, An Immobilized Candida Antarctica Lipase", Bioresources and Bioprocessing, 1:11, 2014.

[17] Miskah, S., Moeksin, R., Reno. dan Sridawati., Pemanfaatan Minyak Goreng Bekas Sebagai Bahan Baku Metil Ester, Jurnal Rekayasa 17 (3), Hal: 15 - 22, 2008. 
[18] Nazir, Novizar., Nazaruddin Ramli, Djumali Mangunwidjaja, Erliza Hambali, Dwi Setyaningsih, Sri Yuliani, Mohd. Ambar Yarmo, Jumat Salimon., "Extraction, Transesterification and Process Control In Biodiesel Production from Jatropha Curcas", Review Article Eur. J. Lipid Sci.Technol, 111, Hal : 1185-1200, 2009.

[19] Seong, Pil-Je, Byoung Wook Jeon, Myunggu Lee, Dae Haeng Cho, Duk-Ki Kim, Kwang S. Jung, Seung Wook Kim, Sung Ok Han, Yong Hwan Kim, Chulhwan Park., "Enzymatic Coproduction of Biodiesel and Glycerol Carbonate from Soybean Oil and Dimethyl Carbonate", Enzyme and Microbial Technology, Vol. 48, pp. 505-509, 2011.

[20] Setyopratomo, Puguh., Purwanto, Edy., Hartanto, Rudy., \& J. Kristianto., "Pengaruh Suhu Reaksi dan Rasio CPO/Metanol terhadap Karakteristik Produk pada Pembuatan Biodisel dengan Co-solvent Dietil Eter", Jurnal Ilmu Dasar, Vol. 9 No. 1, Hal: 72-77, 2008

[21] Silalahi, J., \& Nurbaya, S., "Komposisi, Distribusi, dan Sifat Arterogenik Asam Lemak dalam MinyakKelapa dan Minyak Sawit", Indon Med Assoc, Vol. 61, No. 11, Hal: 453457.

[22] Silalertruksa, Thapat, Sebastien Bonnet, Shabbir H. Gheewala., "Life Cycle Costing and Externalities of Palm Oil Biodiesel in Thailand", Journal of Cleaner Production 28, Hal : 225 - 232, 2012.

[23] SNI, Biodiesel. SNI 04-7182-2006, 2006.

[24] Su E Z, Zhang M J, Zhang J G, Gao J F, Wei D Z. "Lipase-Catalyzed Irreversible Transesterification of Vegetable Oils for Fatty Acid Methyl Ester Production with Dimethyl Carbonate as The Acyl Acceptor". Biochemical Engineering Journal 2007; 36: 167-173.

[25] Su E, You P, Wei D, "In Situ Lipase-Catalyzed Reactive Extraction of Oilseeds with ShortChained Dialkyl Carbonates for Biodiesel Production", Bioresource Technology Journal 2009; 100: 5813-7.

[26] Suganya, T., Kasirajan, R., Renganathan, S., "Ultrasound-Enchanced Rapid In Situ Transesterification Of Marine Macroalgae Enteromorpha compressa For Biodiesel Production", Biosource Technology Vol.156, Hal: $183-290,2014$.
[27] Sulaiman, Sarina., A.R. Abdul Aziz, Mohamed Kheireddine Aroua., "Reactive Extraction of Solid Coconut Waste to Produce Biodiesel", Journal of The Taiwan Institute of Chemical Engineers 44, Hal : 233 - 238, 2013.

[28] Sundaryono, Agus., Karakteristik Biodiesel Dan Blending Biodiesel Dari Oil Losses Cair Pabrik Minyak Kelapa Sawit, J. Tek. Ind. Pert. Vol. 21 (1), Hal: 34-40, 2005.

[29] Taher, Hanifa., Sulaiman Al-Zuhair, Ali H. AlMarzouqi, Yousef Haik, dan Mohammed M. Farid, "A Riview of Enzimatic Tranesterification of Microalgal Oil-Based Biodiesel Using Supercritical Technology", Enzyme Research, Article ID 468292, doi:10.4061/2011/468292, 2011.

[30] Watanabe, Y., Shimada, Y., Sugihara, A., Tominaga, T., "Conversion of Degummed Soybean Oil to Biodiesel Fuel with Immobilized Candida Antartica Lipase, J.Mol.Catal.B Enzyme, Vol. 17, No. 1, Hal: 151-155, 2002.

[31] Wu, Haitang, Yanping Liu, Junhua Zhang, Guanglu Li, "In Situ Reactive Extraction Of Cottonseeds With Methyl Acetate For Biodiesel Production Using Magnetic Solid Acid Ctalysts", Biosource Technology 10, Hal : 026, 2014.

[32] Zakaria, Rabitah dan Adam P. Harvey, "Direct Production Of Biodiesel From Rapeseed By Reactive Extraction/In Situ Transesterification", Fuel Processing Technology, 102, Hal : 53 - 60, 2012.

[33] Zhang, Liping., Shuzhen Sun, Zhong Xin, Boyang Sheng, Qun Liu., "Synthesis and Component Confirmation of Biodiesel from Palm Oil and Dimethyl Carbonate Catalyzed by Immobilized-Lipase in Solvent-Free System”, Fuel 89, Hal : 3960 - 3965, 2010.

[34] Zhao, Xuebing, Feng Qi, Chongli Yuan, Wei Du, Dehua Liu, "Lipase-Catalyzed Process For Biodiesel Production: Enzyme Immobilization, Process Simulation and Optimization", Renewable and Sustainable Energy Reviews, 44, Hal : 182 - 197, 2015.Energy Reviews, 44, Hal : 182 - 197, 2015. 